\title{
ANALISIS DETERMINAN PENGELUARAN KONSUMSI MAKRO RUMAH TANGGA DI INDONESIA
}

\author{
Puspi Eko Wiranthi \\ Institut Pertanian Bogor \\ puspi.eko@yahoo.co.id
}

\begin{abstract}
.
Domination allocation of Gross Domestic Product by its use in household consumption expenditure showed the importance of this type of expenditure to national economic growth and the household welfare. Under these conditions, this study aims to analyze the development of household consumption expenditure in Indonesia during the period 2000 to 2014 and the factors that influence the household consumption expenditure. By using multiple linear regressions, the study finds that the factors of national income, interest rates and fuel prices significantly affect national household consumption expenditure. To further boost economic growth and welfare, the government should imply appropriate policies by increasing household incomes through the expansion of employment opportunities, as well as maintaining the stability of interest rates and minimizing the negative impacts of the rising of oil prices.
\end{abstract}

Keywords: Consumption Expenditures; Multiple Linear Regression; Economic Growth

\begin{abstract}
Abstrak.
Alokasi Produk Domestik Bruto menurut penggunaannya dalam pengeluaran konsumsi rumah tangga menunjukkan pentingnya jenis pengeluaran untuk pertumbuhan ekonomi nasional dan kesejahteraan rumah tangga. Dengan kondisi tersebut, penelitian ini bertujuan untuk menganalisis perkembangan pengeluaran konsumsi rumah tangga di Indonesia selama periode 2000 - 2014 dan faktor - faktor yang mempengaruhi pengeluaran konsumsi rumah tangga. Dengan menggunakan regresi linier berganda, studi ini menemukan bahwa faktor pendapatan nasional, tingkat suku bunga dan harga bahan bakar secara signifikan mempengaruhi pengeluaran konsumsi rumah tangga nasional. Untuk lebih meningkatkan pertumbuhan ekonomi dan kesejahteraan, pemerintah harus membuat kebijakan yang tepat dengan meningkatkan pendapatan rumah tangga melalui perluasan kesempatan kerja, serta menjaga stabilitas suku bunga dan meminimalkan dampak negatif dari kenaikan harga minyak.
\end{abstract}

Kata Kunci: Pengeluaran Konsumsi; Regresi Linear Berganda; Pertumbuhan Ekonomi

Diterima: 5 Agustus 2014; Direvisi: 15 September 2014; Disetujui: 23 September 2014 


\section{PENDAHULUAN}

Indikator pertumbuhan ekonomi Indonesia yang ditunjukkan oleh nilai Produk Domestik Bruto (PDB) selama 13 tahun terakhir telah menunjukkan tren yang positif. Data menunjukkan pada tahun 2013, laju pertumbuhan PDB sebesar 5.78 persen. Angka ini relatif tidak berbeda jauh bila dibandingkan dengan negara lain seperti Malaysia (BPS, 2014). Peningkatan ini disebabkan oleh banyak faktor, di antaranya konsumsi rumah tangga, investasi, pengeluaran pemerintah, dan net ekspor (Kusumawardhani et al., 2012). Dari total PDB tersebut, kontribusi konsumsi rumah tangga diukur melalui pengeluaran konsumsi terdiri dari pengeluaran makanan dan pengeluaran non-makanan memiliki nilai terbesar dari seluruh penggunaan PDB nasional. Meski secara relatif, dari waktu ke waktu proporsi pengeluaran ini mengalami penurunan, dimana pada tahun 1970, proporsi pengeluaran konsumsi dari total alokasi PDB mencapai hampir 80 persen, kemudian pada tahun 1980, proporsinya berkurang menjadi sekitar 60 persen dan ada tahun 2010, proporsinya menurun menjadi sekitar 57 persen, namun secara umum proporsi pengeluaran konsumsi rumah tangga masih menjadi alokasi pengeluaran terbesar dari keseluruhan PDB (BPS, 2014).

Sebagai negara dengan jumlah penduduk lebih kurang 230 juta jiwa, pengeluaran konsumsi rumah tangga menjadi bagian penting yang tidak terpisahkan dari kehidupan sehari-hari masyarakat Indonesia. Tingginya jumlah populasi, menjadikan tingkat konsumsi masyarakat tinggi yang pada akhirnya menyebabkan tingginya permintaan akan barang dan jasa (Raharja dan Manurung, 2008). Tingginya permintaan akan barang dan jasa akan mendorong produksi dan meningkatkan investasi di dalam negeri. Selain sebagai indikator pertumbuhan ekonomi nasional, pengeluaran konsumsi rumah tangga juga merupakan salah satu indikator kesejahteraan rumah tangga yang terukur melalui Indeks Pembangunan Manusia (IPM) dimana hingga saat ini peringkat Indonesia masih berada jauh dibawah negara- negara tetangga, seperi Singapura, Malaysia, Thailand, Filipina, dan bahkan dengan Vietnam (Vera dan Nila, 2008).

Selain itu, indikator kesejahteraan masyarakat juga dilihat dari struktur pengeluaran konsumsi rumah tangga. Pada dasarnya pengeluaran konsumsi rumah tangga dibedakan menjadi pengeluaran makanan dan pengeluaran bukan makanan. Berdasarkan studi empiris yang dilakukan oleh Engel, disebutkan bahwa rumah tangga yang memiliki tingkat pendapatan yang lebih tinggi akan mengalokasikan proporsi 
pengeluaran konsumsi yang lebih tinggi pada konsumsi bukan makanan. Sebaliknya, rumah tangga yang memiliki tingkat pendapatan yang lebih rendah akan mengalokasikan proporsi pengeluaran konsumsi yang lebih tinggi pada konsumsi makanan. Rumah tangga dengan proporsi pengeluaran yang lebih tinggi pada konsumsi bukan makanan menunjukkan tingkat kesejahteraan yang lebih baik daripada rumah tangga dengan proporsi pengeluaran yang lebih tinggi pada konsumsi makanan (Rachman, 2001).

Perilaku konsumsi rumah tangga dapat diamati secara mikro dan makro. Dalam ruang lingkup mikro, perilaku konsumsi rumah tangga dipengaruhi oleh perilaku individu dalam mengambil keputusan konsumsi. Sedangkan dalam ruang lingkup makro, perilaku konsumsi rumah tangga akan mempengaruhi keseluruhan aktivitas perekonomian baik dalam jangka panjang maupun dalam jangka pendek (Mankiw, 2007). Kontribusi yang besar terhadap pertumbuhan ekonomi menyebabkan pentingnya melakukan analisis mengenai faktor-faktor yang mempengaruhi pengeluaran konsumsi rumah tangga nasional.

Secara teoritis, ada beberapa faktor yang mempengaruhi pengeluaran konsumsi rumah tangga secara makro yang dapat dibedakan menjadi faktor ekonomi, faktor nonekonomi dan faktor demografi. Faktor ekonomi yang mempengaruhi pengeluaran konsumsi rumah tangga adalah pendapatan rumah tangga, kekayaan rumah tangga, tingkat bunga dan perkiraan mengenai masa depan. Faktor non-ekonomi yang mempengaruhi pengeluaran konsumsi rumah tangga adalah pola kebiasaan, etika dan tata nilai. Terakhir, faktor demografi yang mempengaruhi pengeluaran konsumsi rumah tangga adalah jumlah dan komposisi penduduk (Rahardja dan Manurung, 2008).

Penelitian terdahulu yang menganalisis mengenai pengeluaran konsumsi rumah tangga di Indonesia menemukan bahwa secara umum faktor-faktor yang mempengaruhi pengeluaran konsumsi rumah tangga di Indonesia adalah pendapatan nasional, tingkat suku bunga, inflasi, pertumbuhan investasi, kenaikan harga Bahan Bakar Minyak (BBM), konsumsi periode sebelumnya [Murohman (2011); Siregar (2009); Persaulian et al. (2013)]. Besarnya proporsi pengeluaran konsumsi rumah tangga dari total PDB nasional menunjukkan kontribusinya yang masih sangat besar terhadap pertumbuhan dan pengembangan ekonomi nasional. Namun, jika dilihat dari proporsi penggunaan PDB relatif dari waktu ke waktu, terdapat indikasi bahwa proporsi yang dialokasikan untuk pengeluaran konsumsi rumah tangga mengalami penurunan dari tahun 1970 
sampai tahun 2013. Sedangkan proporsi alokasi penggunaan PDB pada sektor pembentukan modal dan ekspor impor cenderung menunjukkan peningkatan. Kondisi ini di satu sisi menunjukkan citra positif dari perekonomian nasional, dimana asumsi bahwa masyarakat telah mampu memenuhi konsumsi rumah tangganya dan mengalokasikan sisanya pada investasi telah terpenuhi. Namun, jika dilihat dari sisi lain dimana penelitian menunjukkan bahwa dilihat dari struktur pengeluaran konsumsi, pengeluaran konsumsi rumah tangga untuk makanan masih mendominasi pengeluaran rumah tangga. Kondisi ini menunjukkan bahwa secara umum, tingkat kesejahteraan rumah tangga masyarakat Indonesia masih rendah, khususnya bila dibandingkan dengan negara-negara maju lain.

Adanya faktor-faktor seperti kenaikan harga Bahan Bakar Minyak (BBM) yang terjadi melalui bentuk pengurangan subsidi mengakibatkan proporsi yang dialokasikan masyarakat untuk pengeluaran konsumsi menjadi semakin besar. Kondisi ini pada akhirnya memicu terjadinya inflasi yaitu kenaikan harga barang-barang secara umum. Selain itu, tingkat suku bunga yang tinggi berpotensi mengurangi pengeluaran konsumsi rumah tangga. Tingkat suku bunga yang tinggi akan mengurangi aktivitas konsumsi dikarenakan opportunity cost dari kegiatan konsumsi semakin mahal. Masyarakat akan lebih memilih untuk menyimpan atau menginvestasikan uang mereka daripada melakukan pembelanjaan konsumsi. Kondisi ini secara tidak langsung juga berdampak terhadap pengeluaran konsumsi rumah tangga nasional.

\section{METODE}

Data yang digunakan pada penelitian ini adalah data sekunder runtut waktu (time series) yang diperoleh dari Badan Pusat Statistik (BPS) dan Bank Indonesia (BI) dari tahun 2005 sampai tahun 2013. Variabel-variabel penelitian yang digunakan di dalam penelitian ini terdiri dari variabel dependen dan variabel independen. Variabel dependen adalah pengeluaran konsumsi rumah tangga yang diperoleh dari nilai alokasi PDB terhadap pengeluaran konsumsi rumah tangga baik berupa konsumsi makanan dan bukan makanan atas dasar harga konstan selama periode tahun 2000 sampai 2014. 
Tabel 1. Deskripsi Variabel Penelitian

\begin{tabular}{|c|c|c|c|c|}
\hline Jenis Variabel & Nama Variabel & Jenis Data & Satuan & Sumber \\
\hline Dependen & $\begin{array}{l}\text { Pengeluaran } \\
\text { konsumsi rumah } \\
\text { tangga makro }\end{array}$ & Nominal & Triliun & BPS \\
\hline \multirow[t]{4}{*}{ Independen } & $\begin{array}{l}\text { Pendapatan } \\
\text { nasional }\end{array}$ & Nominal & Triliun & BPS \\
\hline & Tingkat suku bunga & Nominal & persen & Bank Indonesia \\
\hline & Inflasi & Nominal & persen & Bank Indonesia \\
\hline & $\begin{array}{l}\text { Dummy Bahan } \\
\text { Bakar Minyak }\end{array}$ & Nominal & Rupiah & $\begin{array}{l}\text { Kementerian Energi } \\
\text { dan Sumber Daya } \\
\text { Mineral }\end{array}$ \\
\hline
\end{tabular}

Sumber : BPS (2014); BI (2014); (Kementerian ESDM, 2014)

Variabel independen terdiri dari pendapatan nasional, inflasi, tingkat suku bunga, dan harga minyak dunia. Data pendapatan nasional diperoleh dari data PDB dikurangi dengan pendapatan faktor produksi netto dari luar negeri, pajak tidak langsung netto, dan penyusutan penggunaan atas dasar harga konstan tahun 2000 selama periode tahun 2000 sampai 2014. Data suku bunga diperoleh dari Bank Indonesia selama periode tahun 2005 sampai 2013. Data inflasi diperoleh dari perubahan perubahan Indeks Harga Konsumen (IHK) yang telah diolah dengan tahun dasar 2000 selama periode tahun 2000 - 2014. Data harga minyak dunia diperoleh dari Kementerian Energi dan Sumber Daya Mineral (ESDM) (Tabel 1).

Analisis deskriptif dilakukan untuk mendeskripsikan dan menguraikan data penelitian tentang variabel-variabel yang digunakan di dalam penelitian ini. Output yang diharapkan adalah dapat memberikan gambaran umum secara sederhana perkembangan pengeluaran konsumsi rumah tangga secara makro di Indonesia, serta dinamika faktor ekonomi yang mempengaruhinya, meliputi pendapatan nasional (sebagai indikator pertumbuhan ekonomi), jumlah dan suku bunga tabungan, kurs, inflasi, harga minyak dunia (sebagai variabel untuk memproksi harga minyak di dalam negeri).

Penelitian ini menggunakan teknik regresi linear berganda (multiple linear regression model) Model regresi linear berganda diperoleh melalui estimasi terhadap parameterparameternya dengan menggunakan metode kuadrat terkecil (Ordinary Least Square) dan metode kemungkinan maksimum (maximum likelihood estimation) (Kutner et.al., 2004). Tujuan dilakukannya uji normalitas adalah untuk mengetahui apakah residual berdistribusi normal atau tidak, yaitu dengan rata-rata nol dan varian $\sigma^{2}$. Salah satu uji yang digunakan untuk menguji asumsi ini adalah Jarque-Bera test. Uji ini mengukur perbedaan skewness dan kurtosis data kemudian disimpulkan seberapa besar data 
mendekati normalitasnya. Jarque-Bera test menggunakan distribusi chi square $\left(x^{2}\right)$ dengan derajat kebebasan dua. Jika hasil Jarque-Bera test lebih besar dari nilai chi square pada $\alpha=5$ persen, maka error tidak berdistribusi normal.

Multikolinearitas disebabkan karena adanya hubungan linear antara variabel independen di dalam suatu model regresi linear berganda. Multikolinearitas dapat dideteksi dengan menggunakan nilai Variance Inflation Factor (VIF) dimana nilai VIF yang melebihi angka 10 menunjukkan adanya multikolinearitas di dalam model regresi (Gujarati, 2003). Heteroskedastisitas disebabkan karena adanya variansi dari error model regresi linear berganda yang tidak konstan (Widarjono, 2007). Heteroskedastisitas dapat dideteksi melalui beberapa uji, di antaranya uji Gletser dan uji white. Jika hasil uji menunjukkan hipotesis nol $\left(\mathrm{H}_{0}\right)$ ditolak, maka model bebas dari heteroskedastisitas. Pada penelitian ini digunakan uji white yang merupakan generalisasi dari Breusch-Pagan-Godfrey test. Metode ini menggunakan perhitungan perhitungan $\mathrm{R}$-square $\left(\mathrm{R}^{2}\right)$ dari beberapa persamaan yang diregresikan. BreuschPagan test menggunakan distribusi chi square dengan derajat kebebasan satu. Apabila chi square hitung lebih besar dari chi square tabel atau $P$-value $<\alpha$ pada $\alpha=5$ persen, maka tolak hipotesis nol yang berarti terjadi heteroskedastisitas.

Autokorelasi disebabkan karena adanya korelasi antara variabel error di dalam model. Secara umum, autokorelasi terjadi pada data time series (Widarjono, 2007). Untuk mendeteksi terjadinya autokorelasi di dalam model, dapat digunakan melalui metode Durbin-Watson dan uji pengali lagrange (lagrange multiple test) atau yang disebut juga dengan uji Breush-Godfrey (Gujarati, 2003). Pada penelitian ini digunakan BreushGodfrey test.

Model estimasi yang digunakan pada penelitian ini untuk menganalisis variabelvariabel yang mempengaruhi pengeluaran konsumsi rumah tangga adalah sebagai berikut:

CONSUMPTION $_{t}=\beta_{0}+\beta_{1}$ NATIONAL_INCOME $_{t}+\beta_{2}$ INFLATION $_{t}$

$$
+\beta_{3} \text { INTEREST_RATE }{ }_{t}+\beta_{4} \text { DUMMY_OIL_PRICE }{ }_{t}+\varepsilon_{t}
$$

Dimana:

Consumption : : pengeluaran konsumsi rumah tangga secara makro (triliun)

National_income : pendapatan nasional (triliun)

Inflation : laju inflasi (persen)

Interest_rate : : tingkat suku bunga Bank Indonesia (persen)

Dummy_oil_price : harga bahan bakar minyak 


\section{HASIL DAN PEMBAHASAN}

\section{Perkembangan Konsumsi Rumah Tangga secara Makro di Indonesia}

Data menunjukkan bahwa jika dilihat dari angka riil, pengeluaran konsumsi rumah tangga secara makro di Indonesia mengalami kenaikan yaitu sebesar $276 \quad 377,20$ miliar rupiah pada tahun 2000 kemudian menjadi 1518 393,42 miliar rupiah pada tahun 2013. Begitu pula dengan Produk Domestik Bruto yang juga mengalami kenaikan selama periode tersebut. Peningkatan pengeluaran konsumsi rumah tangga ini terjadi karena adanya peningkatan pendapatan rumah tangga yang berasal dari penggunaan faktor-faktor produksi yang dimilikinya meliputi tanah, tenaga kerja, modal dan keahlian kewirausahaan. Aliran faktor-faktor produksi tersebut kepada sektor perusahaan dan pemerintah akan meningkatkan aliran pendapatan ke sektor rumah tangga berupa gaji, bunga, sewa dan profit (Persaulian, 2013).

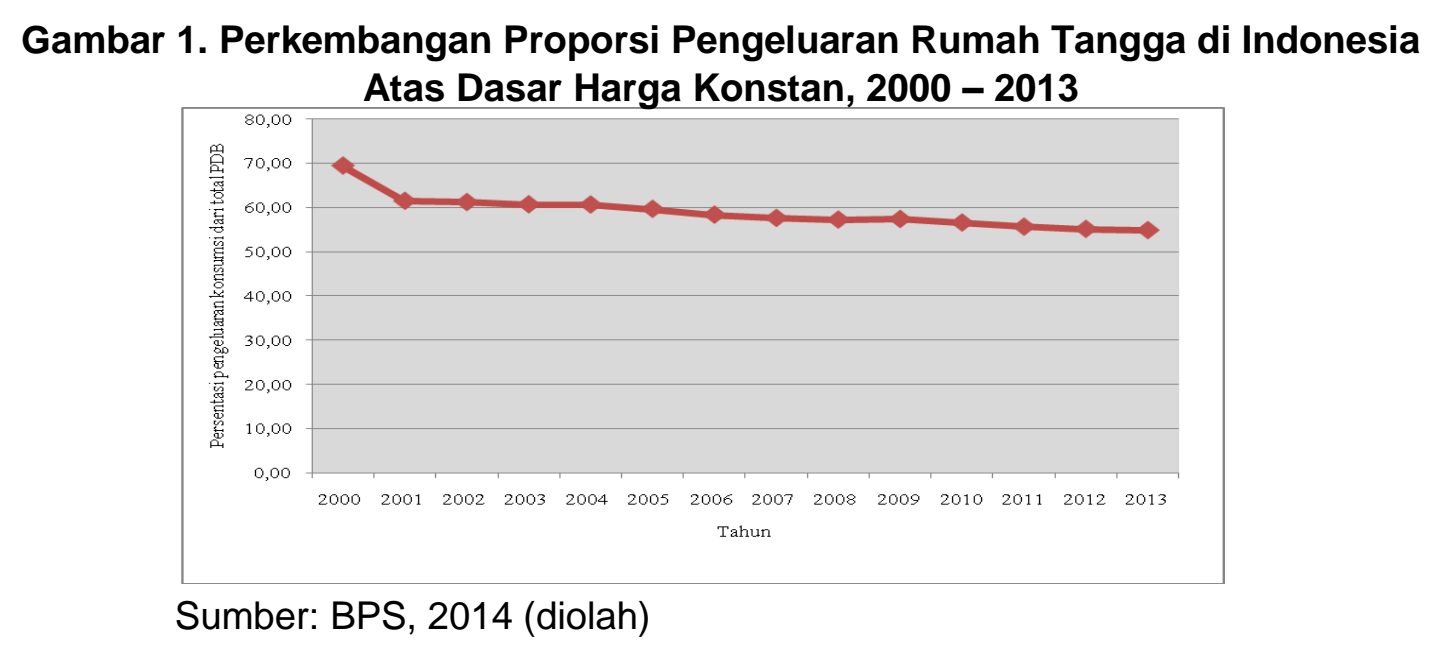

Namun, jika dilihat dari presentase nilai, kontribusi pengeluaran konsumsi terhadap total PDB cenderung mengalami penurunan sejak tahun 2000 sampai tahun 2013. Pada tahun 2000, kontribusi pengeluaran konsumsi rumah tangga masih sebesar 69.44 persen, namun pada tahun 2013 kontribusi pengeluaran rumah tangga hanya sebesar 54.81 persen (Gambar 1). Adanya penurunan proporsi tersebut menunjukkan adanya pergeseran alokasi anggaran konsumen terutama pada pengeluaran pembentukan modal dan ekspor impor. Pada tahun 2013, pertumbuhan ekonomi Indonesia menurut sisi pengeluaran sebanyak 5,30 persen terjadi pada pengeluaran untuk komponen ekspor barang dan jasa, kemudian diikuti dengan pengeluaran konsumsi rumah tangga sebesar 5,28 persen, pengeluaran belanja pemerintah sebesar 4.87 
persen dan pembentukan modal tetap bruto sebesar 4,71 persen (BPS, 2014).

Dilihat dari struktur pengeluaran konsumsi rumah tangga, pengeluaran yang ditujukan untuk bahan makanan memiliki proporsi terbesar. Hal ini jika kita hubungkan dengan hasil studi empirical Engle, ini menunjukkan bahwa tingkat kesejahteraan masyarakat masih rendah. Data tahun 2000 menunjukkan bahwa pengeluaran konsumsi per kapita rumah tangga pada tahun 2000 adalah sebesar 65.81 persen dari total pengeluaran rumah tangga. Pada tahun 2012, angka ini mengalami penurunan menjadi sebesar 51,08 persen (BPS, 2013) (Gambar 2). Kondisi ini menunjukkan adanya indikasi peningkatan pendapatan rata-rata rumah tangga di Indonesia. Adanya peningkatan pendapatan rumah tangga akan mendorong peningkatan proporsi pengeluaran untuk kebutuhan bukan makanan dan menurunkan proporsi pengeluaran untuk kebutuhan makanan.

\section{Gambar 2. Proporsi Pengeluaran Konsumsi Rumah Tangga untuk Makanan dan Bukan Makanan di Indonesia, 2000-2012}

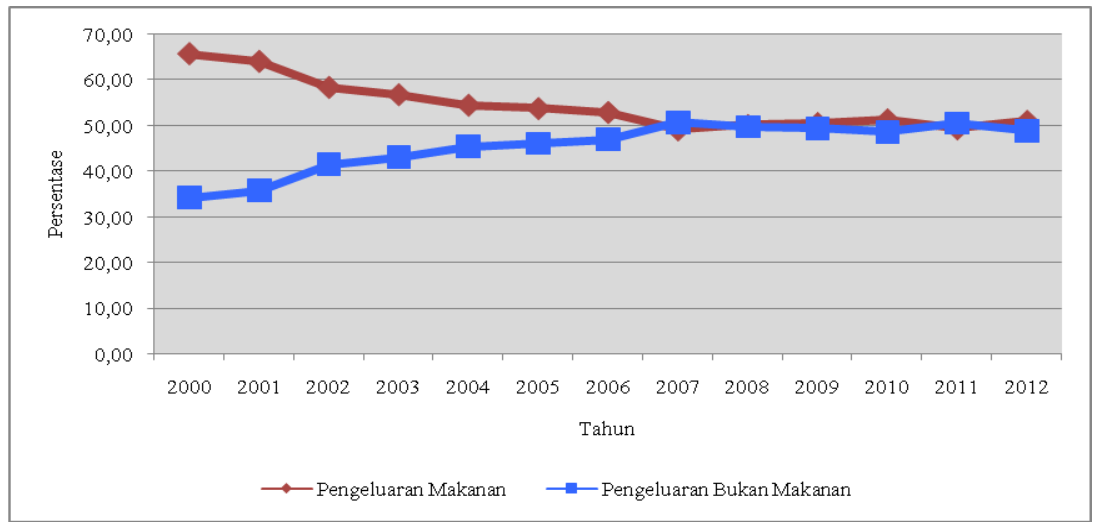

Sumber: BPS, 2013 (diolah)

\section{Pendapatan Nasional}

Data perkembangan pendapatan nasional menunjukkan peningkatan positif selama kurun waktu tahun 2000 sampai tahun 2012. Pada tahun 2000 total pendapatan nasional adalah sebesar 364,471,10 miliar Rupiah. Pada tahun 2012, total pendapatan nasional telah mencapai angka 2,346,192,60 miliar Rupiah. Pendapatan yang digunakan rumah tangga dalam kegiatan konsumsi adalah pendapatan disposable. Data menunjukkan bahwa selama periode tahun 2000 sampai tahun 2008, pendapatan disposable juga mengalami kenaikan di semua golongan rumah tangga (BPS, 2009). Peningkatan ini disebabkan karena adanya peningkatan PDB selama periode tersebut (Gambar 3). 


\section{Gambar 3. Perkembangan PDB, Pendapatan Nasional dan Pengeluaran Konsumsi} Rumah Tangga di Indonesia, 2000 - 2012

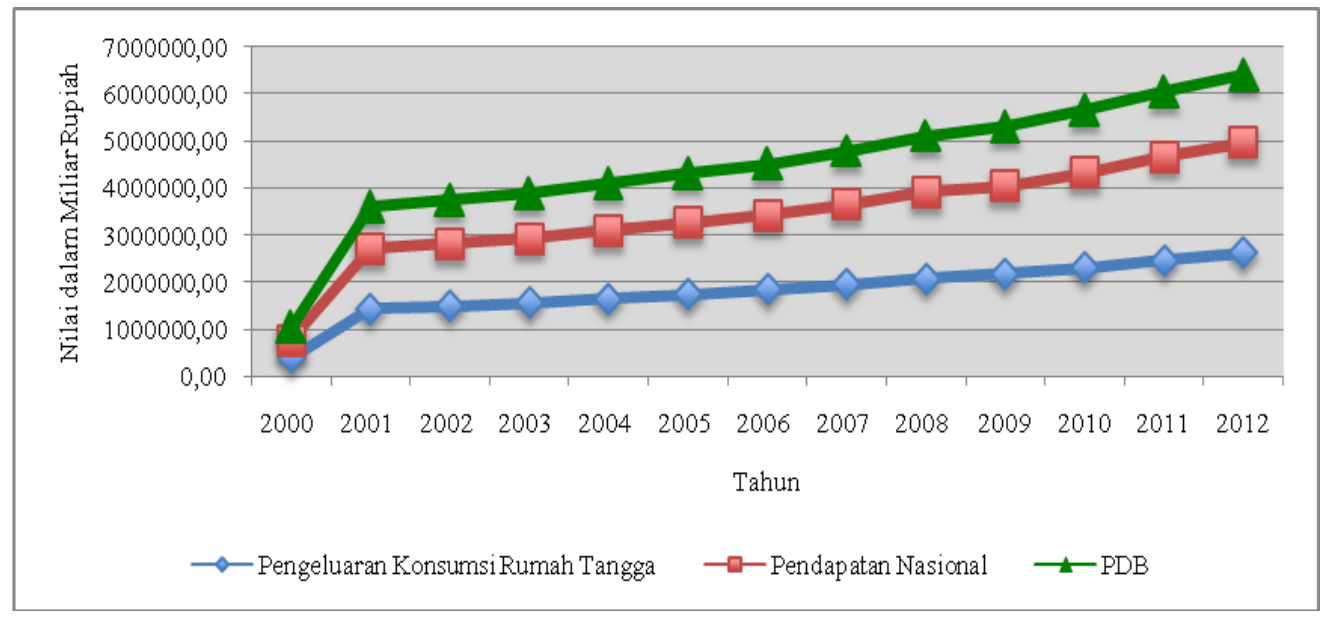

Sumber: BPS, 2013

\section{Inflasi dan Suku Bunga}

Inflasi dapat dilihat dari adanya peningkatan harga secara umum dan terus-menerus. Kondisi ini dapat memengaruhi tingkat konsumsi masyarakat dalam hal fluktuasi daya beli riil masyarakat. Data menunjukkan bahwa laju inflasi di Indonesia dari periode tahun 2000 sampai tahun 2010 cenderung berfluktuatif (Tabel 2). Peningkatan inflasi tanpa disertai dengan peningkatan pendapatan akan mengakibatkan terjadinya penurunan konsumsi rumah tangga. Terjadinya inflasi disebabkan oleh adanya kelebihan peningkatan jumlah uang yang beredar dibandingkan dengan kemampuan dan kesedian masyarakat untuk memiliki atau menyimpan uang tersebut (Khalwaty, 2000).

Tabel 2 menunjukkan bahwa data inflasi tertinggi di Indonesia terjadi pada tahun 2005 yaitu sebesar 17, 11 persen yang disebabkan oleh kenaikan harga BBM di dalam negeri, kurs, jumlah uang yang beredar dan tingkat suku bunga. Sebaliknya data inflasi terendah terjadi pada tahun 2009 yaitu sebesar 2,78 persen yang disebabkan oleh penurunan imported inflation dan kecenderungan apresiasi nilai tukar. Kondisi ini pada tahun yang sama mengakibatkan penurunan konsumsi yang terlihat dari penurunan angka perkembangan konsumsi nasional (Nur, 2012). 
Tabel 2. Perkembangan Inflasi di Indonesia, 2000 - 2013

\begin{tabular}{lcccc}
\hline Tahun & $\begin{array}{c}\text { Konsumsi } \\
\text { (Miliar Rupiah) }\end{array}$ & $\begin{array}{c}\text { Perkembangan } \\
\text { Konsumsi } \\
\text { (persen) }\end{array}$ & $\begin{array}{c}\text { Inflasi } \\
\text { (persen) }\end{array}$ & $\begin{array}{c}\text { Suku Bunga } \\
\text { (persen) }\end{array}$ \\
\hline 2000 & $856.793,3$ & - & 9,35 & 14,53 \\
2001 & $886.736,0$ & 3,49 & 12,55 & 17,62 \\
2002 & $920.749,6$ & 3,84 & 10,03 & 12,99 \\
2003 & $956.593,4$ & 3,89 & 5,06 & 8,31 \\
2004 & $1.003 .109,0$ & 4,86 & 6,40 & 7,43 \\
2005 & $1.043 .805,1$ & 4,06 & 17,11 & 12,75 \\
2006 & $1.076 .928,1$ & 3,17 & 6,60 & 9,75 \\
2007 & $1.130 .847,1$ & 5,01 & 6,59 & 8,00 \\
2008 & $1.191 .190,8$ & 5,34 & 11,06 & 10,83 \\
2009 & $1.249 .011,2$ & 4,85 & 2,78 & 6,46 \\
2010 & $1.306 .800,9$ & 4,63 & 6,96 & 6,45 \\
\hline
\end{tabular}

Sumber: BPS (2014)

Selain inflasi, tingkat suku bunga juga berpengaruh terhadap konsumsi rumah tangga.

Peningkatan tingkat suku bunga riil akan menyebabkan penurunan konsumsi rumah tangga, karena masyarakat akan cenderung meningkatkan pengeluaran untuk tabungan yang memiliki cost of money yang lebih tinggi. Tingkat suku bunga nasional selama periode tahun 2000 sampai 2010 cenderung berfluktuatif. Tingkat suku bunga tertinggi berada pada tahun 2005 yaitu sebesar 12,75 persen yang mengakibatkan terjadinya penurunan persentase perkembangan konsumsi. Hasil pengujian menggunakan Jarque-Bera Test menunjukkan nilai sebesar 0,575 dimana nilai tersebut lebih besar dari $\alpha=5$ persen yang berarti bahwa error pada model berdistribusi normal.

Hasil pengujian ada tidaknya autokorelasi di dalam model dengan menggunakan metode Breusch-Godfrey Serial Correlation LM Test menunjukkan nilai chi-square sebesar 3.162 dengan nilai Probabilitas chi-square hitung sebesar 0.205 dimana nilai tersebut lebih besar dari $\alpha=5$ persen, yang berarti tidak terdapat autokorelasi dalam model (Tabel 3).

Tabel 3. Hasil pengujian Autokorelasi

\begin{tabular}{lcll}
\hline \multicolumn{4}{l}{ Breusch-Godfrey Serial Correlation LM Test: } \\
\hline F-statistic & 1.472621 & Prob. F(2,52) & 0.2387 \\
Obs ${ }^{*}$-squared & 3.162590 & Prob. Chi-Square(2) & 0.2057
\end{tabular}

Sumber: Data, diolah

Hasil pengujian ada tidaknya heteroskedastisitas di dalam model dengan menggunakan metode Breusch-Godfrey Test menunjukkan nilai chi-square sebesar 17,866 dengan nilai Probabilitas chi-square hitung sebesar 0,162 dimana nilai tersebut lebih besar dari $\alpha=5$ persen, yang berarti tidak terdapat heteroskedastisitas dalam model (Tabel 4). 
Tabel 4. Hasil Pengujian Heteroskedastisitas

\begin{tabular}{llll}
\hline Heteroskedasticity Test: White & & \\
\hline F-statistic & 1.503589 & Prob. F(13,45) & 0.1535 \\
Obs*R-squared & 17.86697 & Prob. Chi-Square(13) & 0.1626 \\
\hline
\end{tabular}

Sumber: Data, diolah

Hasil pengujian ada tidaknya multikolinearitas di dalam model dengan melihat korelasi antar variabel di dalam model, dimana tidak terjadi multikolinearitas jika $r$ berada dibawah 0,85 (rule of thumb). Hasil menunjukkan tidak terjadi multikolinearitas di dalam model karena semua nilai $r$ berada di bawah 0.85 .

Koefisien determinasi menjelaskan seberapa besar variabel independen dalam menjelaskan varians dari variabel dependennya. Dalam model diperoleh nilai koefisien $\mathrm{R}^{2}$ sebesar 0.982 yang berarti variabel independen dapat memengaruhi variabel pengeluaran konsumsi rumah tangga sebesar 98,2 persen, selebihnya dapat dijelaskan oleh variabel lain di luar model.

Tabel 5. Hasil Pengujian Multikolinearitas

\begin{tabular}{llcccc}
\hline & CONSUMPTION & $\begin{array}{c}\text { NATIONAL } \\
\text { INCOME }\end{array}$ & INFLATION & $\begin{array}{c}\text { INTEREST } \\
\text { RATE }\end{array}$ & $\begin{array}{c}\text { DUMMY } \\
\text { OIL } \\
\text { PRICE }\end{array}$ \\
\hline CONSUMPTION & 1.000000 & 0.788980 & -0.428003 & -0.660147 & -0.492982 \\
NATIONAL & 0.788980 & 1.000000 & -0.419480 & -0.633567 & -0.486978 \\
INCOME & & & & & \\
INFLATION & -0.428003 & -0.419480 & 1.000000 & 0.573226 & 0.066734 \\
INTEREST RATE & -0.660147 & -0.633567 & 0.573226 & 1.000000 & -0.111829 \\
DUMMY OIL & -0.492982 & -0.486978 & 0.066734 & -0.111829 & 1.000000 \\
PRICE & & & & & \\
\hline
\end{tabular}

Sumber: Data, diolah

Hasil pengolahan data menunjukkan bahwa variabel-variabel secara signifikan yang berpengaruh terhadap pengeluaran konsumsi makro rumah tangga di Indonesia adalah variabel pendapatan nasional dan harga Bahan Bakar Minyak (Tabel 3). Pendapatan nasional berpengaruh signifikan dan memiliki hubungan positif terhadap peningkatan pengeluaran konsumsi rumah tangga dengan Marginal Prospensity to Consume (MPC) sebesar 0,4610. Hal ini menunjukkan setiap peningkatan pendapatan nasional sebesar 1 miliar rupiah akan meningkatkan konsumsi rumah tangga sebesar 0,4610 miliar rupiah, ceteris paribus. Pengaruh pendapatan terhadap konsumsi dalam penelitian sejalan dengan penelitian terdahulu, yang menunjukan bahwa pendapatan berpengaruh positif terhadap pengeluaran konsumsi rumah tangga. Selain itu, hasil ini mendukung teori konsumsi konsumsi dimana konsumsi secara mutlak (absolut) cenderung lebih banyak dipengaruhi tingkat 
pendapatan sekarang dan nilainya berada di antara 0 dan 1 (asumsi Keynes) (Murohman, 2011).

Tabel 6. Hasil Estimasi Koefisien Regresi Linier Berganda

\begin{tabular}{llll}
\hline \multicolumn{1}{r}{ Variable } & \multicolumn{1}{c}{ Coefficient } & \multicolumn{1}{c}{ t-Statistic } & \multicolumn{1}{c}{ Prob. } \\
\hline NATIONAL_INCOME & 0.461080 & 26.25940 & 0.0000 \\
INFLATION & 1950.770 & 0.688243 & 0.4942 \\
INTEREST_RATE & -208154.6 & -3.616984 & 0.0007 \\
DUMMY_OIL_PRICE & -10674.54 & -2.924881 & 0.0050 \\
Constant & 107240.7 & 8.536267 & 0.0000 \\
R-squared & 0.982725 & Prob(F-statistic) & 0.000000 \\
Adjusted R-squared & 0.981445 & &
\end{tabular}

Sumber : Data, diolah

Kenaikan harga Bahan Bakar Minyak berpengaruh signifikan dan memiliki hubungan negatif terhadap peningkatan pengeluaran konsumsi rumah tangga, dimana jika terjadi kenaikan harga BBM maka pengeluaran konsumsi rumah tangga secara makro akan mengalami penurunan sebesar -10 674,54 miliar, ceteris paribus. Tingkat suku bunga berpengaruh signifikan dan memiliki hubungan negatif terhadap pengeluaran konsumsi rumah tangga. Kenaikan suku bunga sebesar 1 persen akan menurunkan pengeluaran konsumsi rumah tangga sebesar -208154.6 miliar, ceteris paribus. Hasil ini sejalan dengan hasil penelitian Murohman (2011), Siregar (2009) dan Persaulian et.al. (2013) dimana adanya kenaikan suku bunga akan mendorong masyarakat untuk mengalihkan sebagian besar pendapatan mereka untuk ditabung karena mempertimbangkan cost of money dalam jangka panjang.

Nilai F-hitung dari hasil regresi signifikan pada $\alpha=5$ persen dengan nilai sebesar 0,000 . Kondisi ini menunjukkan variabel independen yang digunakan dalam model secara bersama-sama memiliki pengaruh yang sangat signifikan terhadap variabel pengeluaran konsumsi rumahtangga dan model yang digunakan cukup baik untuk mengestimasi variabel dependen.

\section{SIMPULAN}

Pengeluaran konsumsi rumah tangga memiliki kontribusi yang sangat besar berdasarkan alokasi penggunaan PDB terhadap pertumbuhan perekonomian dan tingkat kesejahteraan masyarakat. Namun kontribusi pengeluaran konsumsi terhadap total PDB cenderung mengalami penurunan sejak tahun 1970 sampai tahun 2013. Pada tahun 1970, proporsi pengeluaran konsumsi dari total alokasi PDB mencapai hampir 80 persen. Pada tahun 2000, kontribusi pengeluaran konsumsi rumah tangga 
menurun menjadi sebesar 69.44 persen, dan pada tahun 2013 kontribusi pengeluaran rumah tangga hanya sebesar 54.81 persen.

Kondisi ini dapat menjadi indikasi positif bahwa masyarakat mulai mengalihkan alokasi pendapatan ke sektor pembentukan modal dan ekspor impor. Begitu pula dari indikator besarnya pangsa pengeluaran yang dialokasikan untuk makanan yang cenderung mengalami penurunan. Sebaliknya, besarnya pangsa pengeluaran yang dialokasikan untuk bukan makanan cenderung mengalami kenaikan. Kondisi ini memberikan indikasi positif adanya peningkatan tingkat kesejahteraan masyarakat. Faktor-faktor yang signifikan mempengaruhi pengeluaran konsumsi rumah tangga adalah pendapatan nasional, tingkat suku bunga dan harga Bahan Bakar Minyak. Hasil analisis ini diharapkan dapat memberikan masukan bagi penguatan kebijakan pemerintah dalam upaya meningkatkan pertumbuhan ekonomi nasional.

\section{PUSTAKA ACUAN}

Badan Pusat Statistik. 2014. Produk Domestik Bruto Atas Dasar Harga Konstan 2000 Menurut Lapangan Usaha (Miliar Rupiah) 2000-2013. http://www.bps.go.id/tab_sub/view.php?kat=2\&tabel=1\&daftar=1\&id_subyek=11 $\&$ notab $=3$.

Badan Pusat Statistik. 2014. Penggunaan Produk Domestik Bruto Triwulanan Atas Dasar Harga Konstan, 2010-2014 (Miliar Rupiah). http://www.bps.go.id/tab_sub/view.php?kat=2\&tabel=1\&daftar=1\&id_subyek=11 $\&$ notab $=41$.

Badan Pusat Statistik. 2014. Penggunaan Produk Domestik Bruto Atas Dasar Harga Konstan, 2000-2012 (Miliar Rupiah). http://www.bps.go.id/tab_sub/view.php?kat=2\&tabel=1\&daftar=1\&id_subyek=11 $\&$ notab $=86$.

Badan Pusat Statistik. 2014. Pertumbuhan PDB Tahun 2013 Mencapai 5,78 Persen. http://www.bps.go.id/brs_file/pdb_05feb14.pdf.

Badan Pusat Statistik. 2014. Persentase Pengeluaran Rata-Rata per Kapita Sebulan Menurut Kelompok Barang, 1998-2012. http://www.bps.go.id/tab sub/view.php?kat=1\&tabel=1\&daftar=1\&id subyek=05 \&notab=14.

Badan Pusat Statistik. 2014. Nilai Pendapatan disposabel menurut golongan rumah tangga (miliar rupiah), 2000, 2005, dan 2008. http://www.bps.go.id/tab sub/view.php?kat=1\&tabel=1\&daftar=1\&id subyek=05 \&notab=31.

Gujarati ND. 2003. Basic Econometrics. Ed ke-4. New York: Mc Graw Hill Companies Inc. 
Khalwaty T. 2000. Inflasi dan Solusinya. Jakarta: PT Gramedia Pustaka Utama.

Kusumawardhani NMS, Ayu MS, Made S. 2012. Faktor-Faktor yang Mempengaruhi PDB Indonesia dengan Persamaan Simultan 2 SLS. E-Jurnal Matematika. 1(1): 99-102.

Kutner MH, Nachtsheim CJ, Neter J. 2004. Applied Linear Regression Models. Ed ke-4. New York : Mc Graw Hill Companies Inc.

Mankiw NG. 2007. Makroekonomi. Ed ke-6. Fitria Liza dan Imam Nurmawan [penterjemah]. Jakarta (ID) : Erlangga.

Murohman. 2011. Analisis Faktor-Faktor yang Memengaruhi Pengeluaran Konsumsi Rumah Tangga di Indonesia (Periode Tahun 2000-2010) Skripsi Tidak Dipublikasikan. Bogor : Institut Pertanian Bogor.

Nur EM. 2012. Konsumsi dan Inflasi di Indonesia. Jurnal Kajian Ekonomi. 1(1):55-77.

Persaulian B, Hasdi A, Ali A. 2013. Analisis Konsumsi Masyarakat di Indonesia. Jurnal Kajian Ekonomi. 1(2): 1-23.

Rachman HPS. 2001. Kajian Pola Konsumsi dan Permintaan Pangan Masyarakat Berpendapatan Rendah Jawa Tengah dan Nusa Tenggara Barat. Jurnal Agro Ekonomi. 15 (2) : 36-53.

Rahardja, P dan M Manurung. 2008. Pengantar IImu Ekonomi (Mikroekonomi \& Makroekonomi). Ed ke-3. Jakarta: Lembaga Penerbit FEUI.

Siregar K. 2009. Analisis Determinan Konsumsi Masyarakat di Indonesia. Tesis Tida Dipublikasikan, Medan : Universitas Sumatera Utara.

Vera L, Nila R. 2008. Analisis Faktor-Faktor Ekonomi Makro Yang Mempengaruhi Tingkat Konsumsi Era Pemerintahan SBY Jilid I (2004- 2008). Tesis Tidak Dipublikasiklan, Bogor : Institut Pertanian Bogor.

Widarjono A. 2007. Ekonometrika: Teori dan Aplikasi untuk Ekonomi dan Bisnis. Ed ke2. Yogyakarta : Fakultas Ekonomi Universitas Islam Indonesia. 